\title{
Effect of Soaking, Cooking, Germination and Fermentation Processing on Physical Properties and Sensory Evaluation of Sorghum Biscuits
}

\author{
Abd El-Moneim M. R. AFIFY' ${ }^{1}$ Hossam S. EL-BELTAGI ${ }^{1 *}$, \\ Samiha M. ABD EL-SALAM ${ }^{2}$, Azza A. OMRAN² \\ IDepartmentofBiochemistry, Faculty of Agriculture,Cairo University, Giza, Cairo,Egypt; abdelmoneimafify@yahoo.com, lbltg@yahoo.com (*orrespondingauthor) \\ ${ }^{2}$ Department of Crops Technology, Food Technology Research Institute, Agricultural Research Center, Giza, Egypt; \\ samiha_abdelsalam@yahoo.com; azzaa_omran@yahoo.com
}

\begin{abstract}
Three white sorghum varieties (named 'Dorado', 'Shandaweel-6' and 'Giza-15') were investigated for grain characteristics and processed whole meal flour (via soaking, cooked, germinated and fermented sorghum). 'Giza-15' variety was the highest one in 1,000 kernel weight and hectolitre, followed by 'Dorado' and 'Shandaweel-6' that were significant lower. Sorghum varieties were non-significant different in L scales. 'Giza-15' was the highest variety in a and b scales. Sorghum varieties were significant different in c scales and nonsignificant different in h scales. 'Shandaweel-6' recorded the highest value in water holding capacity (WHC). 'Giza-15' recorded the highest variety in oil holding capacity $(\mathrm{OHC})$. The most significant increase in WHO was after fermentation treatment, followed by cooking treatment. Regarding $\mathrm{OHC}$, the most significant increase was after germination treatment. Biscuits prepared from $50 \%$ whole meal flour of raw, soaked, cooked, germinated and fermented sorghum were evaluated for sensory and physical characteristics. The sensory results showed that $50 \%$ sorghum whole meal flour could be incorporated to prepare acceptable quality biscuits. The diameter of sorghum biscuits increased, while the diameter of wheat biscuits decreased. Hardness of sorghum biscuits was significant decreased in all treatments compared with wheat biscuits. Hardness of germinated sorghum biscuits was close to wheat biscuits values.
\end{abstract}

Keywords: sorghum, grain characteristics, functional properties, biscuit, sensory and physical characteristics

\section{Introduction}

Sorghum (Sorghum bicolour L. Moench) belongs to the family Gramineae, including both wild and cultivated sorghum. Sorghum is the fifth important crop among the cereals in the world following rice, wheat, maize and barley, in total area planted and production (Onwueme and Sinha, 1993). Sorghum is a principal cereal that forms an important staple diet throughout the semiarid Asian and African regions (Ahmed et al., 2000). The nutrient composition of sorghum indicates that it is a good source of energy, proteins, carbohydrates, oils, polyunsaturated fatty acid (PUFA), vitamins and minerals (Afify et al., 2011a; Afify et al., 2012a, b, c, d; Dicko et al., 2006). Sorghum has good quality proteins which are readily digestible and contains the essential amino acids in quantities that correspond to human requirements (Afify et al., 2011b; El-Beltagi, 2011; El-Beltagi et al., 2011; Zhao et al., 2008).

Sorghum is grown for grain, forage, syrup and sugar. The total consumption of sorghum closely follows the global patterns of output, since most of it is consumed in the countries where is grown (FAO/WFP, 2007). The color of sorghum grain varies greatly due to pericarp color and thickness, presence of testa, endosperm texture and color. The relationship between sorghum color and tannin content was previously reported.

Traditional treatments such as soaking, cooking, germinating and fermenting have been used to improve nutritional quality of the legume (Hahn and Rooney, 1985). Food processing technologies can contribute to the alleviation of micronutrient deficiencies (Traoré et al., 2004; Kayodé, 2006). Process operations that decrease the level of antinutritional factors and that minimize the losses of micronutrients are of interest. Mechanical, thermal or biological processes have the potential to improve the nutrient availability in foods (Kayodé, 2006). Germination is a common practice in sorghum producing areas. Grains are malted for the production of weaning foods, opaque beers and other traditional dishes (Elkhalifa and Bernhardt, 2010).

Sorghum was used in production of ready to eat products by using extrusion cooking technology and gun-puffing in Southern Africa. Some reports exist on antioxidant activity of fully processed products like cookies and bread containing sorghum bran, as well as extrusion cooked products (Awika et al., 2003). Whole sorghum grain could be used in baked, extruded and other cereal-based products (bread, cookies, expanded snacks, pasta, breakfast cereals etc.) as 
130

partial or complete substitutes for other cereals (Awika and Rooney, 2004).

The future promise of sorghum in the developed countries is referring to wheat substitution for people allergic to gluten (Ciacci et al., 2007). Sorghum is often recommended as a safe food for celiac patients, those with a negative autoimmune response to wheat gluten and similar proteins in rye and barley (Pontieri et al., 2010).

Biscuits are ready to eat, cheap and convenient food products that are consumed among all age groups in many countries (Hussein et al., 2006; Iwegbue, 2012). Biscuits were reported to be rich in fat and carbohydrates, hence they could be referred as energy giving food, as well as a good source of proteins and minerals (Kure et al., 1998). The rapid urbanization and increase in population in recent years have resulted in wheat-based products consumption, especially biscuits, in sub-Saharan Africa (Adebowale et al., 2012).

Compositing wheat flour with locally available cereals and root crops was desirable (Oyarekua and Adeyeye, 2009). It also encourages the agricultural sector and focused on the use of composite flour for bread and baked products in many wheat importing countries within the last two and half decades (Mepba et al., 2005; Mohammed et al., 2011).

The aim of this study was to evaluate the grain characteristics and the effects of raw, soaked, cooked, germinated and fermented sorghum on sensory and physical characteristics of sorghum biscuits.

\section{Materials and methods}

\section{Samples}

Three white sorghum varieties (Sorghum bicolour L. Moench), were chosen due to their highly production in Egyptian areas and obtained from the Crops Research Institute, Agricultural Research Center, named 'Shandaweel6', 'Dorado' and 'Giza-15'. The grains were carefully cleaned and freed from broken grains and extraneous matter.

\section{Grain characterization}

Physical properties of sorghum grains

Sorghum grains were analyzed for physical parameters: thousand kernel weight, kernel density and hectolitre, according to Almeida-Dominguez and Rooney (1997).

\section{Measurement of sorghum grains color}

External color of raw sorghum grain was measured on opposite sides of the grains by using a hand-held Tristimulus reflectance colorimeter according to Awika et al. (2002).

\section{Treatments of sorghum grains}

Sorghum grains were soaked in distilled water for $20 \mathrm{~h}$ with a ratio $1: 5 \mathrm{w} / \mathrm{v}$ and the soaking water was changed twice. The grains were rinsed twice with distilled water and dried in drying oven at $45 \pm 5^{\circ} \mathrm{C}$. The dried soaked grains were milled and kept until analysis. Germination, cooking and fermentation treatments were carried out on the soaked grains. Then, soaked grains were germinated for $72 \mathrm{~h}$ or cooked for 10 min (based on pre-experiments to choose the suitable treatment and conditions). The germinated and cooked grains were dried, milled and kept until analysis. Fermentation obtained from whole meal flour of dried soaked grains $(20 \mathrm{~h}$ ). Flour was cooked by boiling with sufficient amount of distilled water for $10 \mathrm{~min}$ and fermented for $12 \mathrm{~h}$. Then the obtained slurry was dried, milled and kept until analysis.

\section{Functional properties of milled sorghum before and after} treatment

Water and oil-binding capacity was performed according to the method of Beuchat (1977). Two grams of each milled sample $\left(W_{1}\right)$ were weighed into a pre-weighed centrifuge tube $\left(\mathrm{W}_{2}\right)$ and $20 \mathrm{ml}$ of distilled water or sunflower oil respectively, were added. Samples were vortexed and allowed to stand for $30 \mathrm{~min}$ at $25 \pm 2^{\circ} \mathrm{C}$ before being centrifuged at $4,000 \mathrm{~g}$ for $25 \mathrm{~min}$. Excess water or oil was decanted by inverting the tubes over absorbent paper and samples were allowed to drain and reweighed $\left(\mathrm{W}_{3}\right)$. The percentage of water or oil holding capacity were calculated as:

$$
\mathrm{WHC} \text { or } \mathrm{OHC} \%=\frac{\mathrm{W} 3-\mathrm{W} 2}{\mathrm{~W} 1} \mathrm{X} 100
$$

\section{Biscuitspreparation}

Biscuit samples were prepared according to the method described by Whiteley (1971) with minor modifications from Omobuwajo (2003). Biscuit formula consisted of $50 \mathrm{~g}$ milled sorghum (whole meal flour), $50 \mathrm{~g}$ of wheat flour (72\% extraction rate), $30 \mathrm{~g}$ fat (milk butter), $32 \mathrm{~g}$ sugar, $2 \mathrm{~g}$ powdered milk, $1 \mathrm{~g}$ salt, $0.4 \mathrm{~g}$ sodium bicarbonate, $0.27 \mathrm{~g}$ ammonium bicarbonate and $0.2 \mathrm{~g}$ vanilla. Fat, sugar and vanilla were mixed in a dough mixer to obtain a homogenous cream. Flour and other ingredients were added to the mixture and homogenised. After that, the obtained dough was cut in circular pieces using templates and baked. The biscuits were allowed to cool then subjected to organoleptic and physically evaluations.

\section{Organoleptic evaluation of biscuits}

Biscuit samples were organolyptically evaluated for their sensory characteristics: appearance, color, odor, texture, taste and overall acceptability. The evaluation was carried out according to the method of Larmond (1977).

\section{Physical characteristics of biscuits}

Biscuits were evaluated for weight $(\mathrm{g})$, thickness $(\mathrm{mm})$, diameter $(\mathrm{mm})$, density $(\mathrm{g} / \mathrm{cm})$ and spread ratio as described by Gaines (1991). Five biscuits were used for the evaluation and the average was noted. Spread ratio was calculated from the ratio of diameter to thickness and calculated using the following equation:

\section{Spread ratio $=$ Diameter $/$ Thickness}

\section{Determination of biscuit hardness}

The maximum force required to break the biscuits was measured as described by Gaines (1991). The hardness of biscuits was measured by using a three point test on a Universal testing machine. The compression strength of biscuits was measured at a $20 \%$ level of compression with a cross-head speed of $100 \mathrm{~mm} / \mathrm{min}$ and a flat ended probe $(2.5$ $\mathrm{mm}$ thickness). All measurements were performed at ambient temperature $20^{\circ} \mathrm{C}$. The hardness was recorded by Newton $(\mathrm{N})$.

\section{Statistic analysis}

For the analytical data, mean values and standard deviation are reported. The data obtained were subjected to 
one-way analysis of variance (ANOVA) and least significant difference (LSD) test, at $P<0.05$.

\section{Results and discussions}

\section{Physical properties of sorghum varieties}

Table 1 displays the weight of 1,000 kernel, density and hectoliter of sorghum grain. The data indicated that the weight of 1,000 kernels ranged from 28.61 to $37.44 \mathrm{~g}$. 'Giza15 ' variety was the highest variety in 1,000 kernel weight, followed by 'Dorado' and 'Shandaweel-6', which were significant lower in weight of 1000 kernels. The results approved earlier studies that found that weight of 1,000 kernel in sorghum varieties ranged from 27.90 to $35.10 \mathrm{~g}$, 23.00 to $32.00 \mathrm{~g}$ and 26.86 to $33.42 \mathrm{~g}$, respectively (Awika $e t$ al., 2002; Ogu et al., 2006; Okrah, 2008). The weight of 1,000 kernel in sorghum varieties obtained by Ndirika and Mohammed (2005) was $31.51 \mathrm{~g}$. Densities of grains varied from 1.13 to $1.18 \mathrm{~g} / \mathrm{cm}^{3}$ for the three varieties and showed non-significant differences. The results are in agreement with previous study which reported that sorghum density ranged from 1.161 to $1.472 \mathrm{~g} / \mathrm{cm}^{3}$ (Mwithiga and Sifuna, 2006). Hectoliter values of sorghum grains were significant different between the varieties $(75.63,76.20$ and $83.28 \mathrm{~kg} / \mathrm{hl}$ for

Table 1. Physical properties of sorghum varieties

\begin{tabular}{lccc}
\hline \multicolumn{1}{c}{ Varieties } & $\begin{array}{c}1000 \text { kernel } \\
\text { weight }(\mathrm{g})\end{array}$ & $\begin{array}{c}\text { Density } \\
(\mathrm{g} / \mathrm{cm} 3)\end{array}$ & $\begin{array}{c}\text { Hectoliter* }^{*} \\
(\mathrm{~kg} / \mathrm{hl})\end{array}$ \\
\hline 'Dorado' & $29.28 \pm 0.66^{\mathrm{b}}$ & $1.17 \pm 0.04^{\mathrm{a}}$ & $76.20 \pm 0.23^{\mathrm{b}}$ \\
'Shandaweel-6' & $28.61 \pm 1.18^{\mathrm{b}}$ & $1.18 \pm 0.05^{\mathrm{a}}$ & $75.63 \pm 0.45^{\mathrm{b}}$ \\
'Giza-15' & $37.44 \pm 0.37^{\mathrm{a}}$ & $1.13 \pm 0.02^{\mathrm{a}}$ & $83.28 \pm 0.59^{\mathrm{a}}$ \\
L.S.D & 1.2927 & 0.0649 & 0.7184 \\
\hline
\end{tabular}

*Kilogram per hectoliter or 100 liter

Values are mean of three replicates $\pm S D$, values in the same column followed by the same letter are not significantly different at 0.05 level

'Shandaweel-6', 'Dorado' and 'Giza-15', respectively) and 'Giza-15' was the highest variety in hectolitre analysis.

\section{Color of sorghum grains}

Kernel color determination is important because the information obtained helps in anticipating end-product color quality (Fathi et al., 2006; Wan et al., 2011; Afshari-Jouybari and Farahnaky, 2011).

Table 2 presents the color of sorghum grains. Data showed that the grain lightness nearly result in the same scales for the three varieties of sorghum (ranged from 62.27 to 63.53). Similar results were obtained by Lee et al. (2002), L scales in raw sorghum ranged from 60.13 to 66.40 . Whiter grains have higher $L$ scales, while grains with dark or red pericarp have lower L scales (Ngwenya, 2007).The data indicated that a and b scales ranged from 3.51 to 4.54 and 24.02 to 27.42 , respectively. 'Giza-15' was the highest variety

Table 2. Color of sorghum grains

\begin{tabular}{cccccc}
\hline Varieties & $\mathrm{L}$ & $\mathrm{a}$ & $\mathrm{b}$ & $\mathrm{c}$ & $\mathrm{h}$ \\
\hline 'Dorado' & $62.51 \pm 0.53^{\mathrm{a}}$ & $3.66 \pm 0.25^{\mathrm{b}}$ & $24.02 \pm 0.56^{\mathrm{b}}$ & $24.27 \pm 0.49^{\mathrm{b}}$ & $81.90 \pm 1.35^{\mathrm{a}}$ \\
'Shandaweel-6' & $63.53 \pm 0.30^{\mathrm{a}}$ & $3.51 \pm 0.06^{\mathrm{b}}$ & $24.36 \pm 0.99^{\mathrm{b}}$ & $24.61 \pm 0.99^{\mathrm{b}}$ & $81.79 \pm 0.20^{\mathrm{a}}$ \\
'Giza-15' & $62.27 \pm 1.01^{\mathrm{a}}$ & $4.54 \pm 0.23^{\mathrm{a}}$ & $27.42 \pm 0.02^{\mathrm{a}}$ & $27.79 \pm 0.02^{\mathrm{a}}$ & $80.59 \pm 0.49^{\mathrm{a}}$ \\
L.S.D & 1.3527 & 0.4018 & 1.3200 & 1.2795
\end{tabular}

${ }^{*} \mathrm{~L}$ (lightness with $\mathrm{L}=100$ for lightness, and $\mathrm{L}=0$ (zero) for darkness, a [(chromaticity on a green $(-)$ to red $\left.(+)\right]$, b $[($ chromaticity on a blue $(-)$ to yellow $(+)]$, c (color saturation $), \mathrm{h}\left[\left(\right.\right.$ hue angle where $0^{\circ}=$ red to purple, $90^{\circ}=$ yellow, $180^{\circ}=$ bluish to green and $270^{\circ}=$ blue scale

Values are mean of three replicates $\pm S D$, values in the same column followed by the same letter are not significantly different at 0.05 level

in $\mathrm{a}$ and $\mathrm{b}$ scales and significant different compared with other varieties. These results are close to other study who found that a scale ranged from 0.40 to 4.50 in different sorghum varieties (da Silva and Taylor, 2004). The $\mathrm{c}$ and h scales ranged from 24.27 to 27.79 and 80.59 to 81.90 , respectively. Sorghum varieties were significant different in c scales and non-significant different in $\mathrm{h}$ scales.

\section{Water and oil holding capacity}

Table 3 exhibits water and oil holding capacity (WHC and $\mathrm{OHC}$ ) of milled sorghum at different treatments. Data showed that WHC and OHC of raw sorghum ranged from 112.92 to $125.68 \%$ and 60.61 to $72.62 \%$, respectively. 'Shandaweel-6' recorded the highest value in WHC. 'Giza-15' recorded the highest variety in OHC. Sorghum flour had higher oil-holding capacity and this suggests that this flour would be useful in food formulations where an oil holding property is an important consideration (Elkhalifa et al., 2005).

The most significant increase in WHO was after the fermentation treatment, followed by cooking treatment. Sorghum flour, fermented and unfermented, has a higher water and oil binding capacity (Akpata and Miachi, 2001). Germination and fermentation give rise to increase WHC (Gernah et al., 2011).

Table 3. WHC and OHC of milled sorghum at different treatments (\%)

\begin{tabular}{lcc}
\hline Treatments & WHC & OHC \\
\hline Raw & & \\
'Dorado' & $122.25 \pm 0.35^{\mathrm{gh}}$ & $60.61 \pm 1.20^{\mathrm{h}}$ \\
\hline 'Shandaweel-6' & $125.68 \pm 1.79^{\mathrm{fg}}$ & $64.83 \pm 2.42^{\mathrm{g}}$ \\
\hline 'Giza-15' & $112.92 \pm 0.32^{\mathrm{i}}$ & $72.62 \pm 1.89^{\mathrm{ef}}$ \\
\hline Soaking & & \\
'Dorado' & $126.54 \pm 3.31^{\mathrm{f}}$ & $69.35 \pm 0.16^{\mathrm{f}}$ \\
\hline 'Shandaweel-6' & $129.50 \pm 1.06 \mathrm{f}$ & $68.60 \pm 3.12 \mathrm{fg}$ \\
\hline 'Giza-15' & $118.40 \pm 0.65_{\mathrm{h}}$ & $68.93 \pm 0.17 \mathrm{fg}$ \\
\hline Cooking & & \\
\hline 'Dorado' & $167.68 \pm 3.45^{\mathrm{e}}$ & $70.94 \pm 2.95^{\mathrm{ef}}$ \\
\hline 'Shandaweel-6' & $174.23 \pm 3.83^{\mathrm{d}}$ & $78.22 \pm 2.66^{\mathrm{cd}}$ \\
\hline 'Giza-15' & $173.99 \pm 0.10^{\mathrm{d}}$ & $74.78 \pm 1.88^{\mathrm{de}}$ \\
\hline Germination & & \\
\hline 'Dorado' & $122.38 \pm 0.10^{\mathrm{gh}}$ & $85.47 \pm 2.01^{\mathrm{b}}$ \\
\hline 'Shandaweel-6' & $129.82 \pm 1.36^{\mathrm{f}}$ & $88.90 \pm 3.16^{\mathrm{b}}$ \\
\hline 'Giza-15' & $119.19 \pm 2.52^{\mathrm{h}}$ & $94.94 \pm 2.20^{\mathrm{a}}$ \\
\hline Fermentation & & \\
\hline 'Dorado' & $256.83 \pm 2.67^{\mathrm{a}}$ & $76.88 \pm 2.15^{\mathrm{cd}}$ \\
\hline 'Shandaweel-6' & $249.40 \pm 3.78^{\mathrm{b}}$ & $79.30 \pm 1.85^{\mathrm{c}}$ \\
\hline 'Giza-15' & $232.48 \pm 3.63^{\mathrm{c}}$ & $71.74 \pm 3.14^{\mathrm{ef}}$ \\
\hline L.S.D & 3.8393 & 3.9305 \\
\hline
\end{tabular}

* WHC and $\mathrm{OHC}=$ water and oil holding capacity Values are mean of three replicates $\pm \mathrm{SD}$, values in the same column followed by
the same letter are not significantly different at 0.05 level 
132

Germinated and fermented flours absorbed more water, with non-significant differences. This increased solubility could be as a result of the increase in the amount of soluble sugars present in the germinated and fermented flours. Also, increased water absorption of flours and fermented sorghum showed increased WHC values over the unfermented. During fermentation, proteolytic activity takes place, which cause the increase in the number of polar groups and hydrophility of the flour proteins (Elkhalifa and El-Tinay, 2002; Etudaiye et al., 2009).

Regarding $\mathrm{OHC}$, the most significant increase of $\mathrm{OHC}$ was after the germination treatment. $\mathrm{OHC}$ increase after germination and this could be attributed to the change in the quality of proteins upon germination. Since the binding of the oil depends on the surface availability of hydrophobic amino acids, the enhancement in $\mathrm{OHC}$ of the germinated samples could be attributed to an increase in the availability of these amino acids by unmasking the non-polar residues from the interior protein molecules. OHC has been attributed to the physical entrapment of oil (Elkhalifa and El-Tinay, 2002; Osungbaro et al., 2010).

\section{Technological evaluation \\ Organoleptic characteristics of biscuits}

One of the limiting factors for consumers' acceptability is the organoleptic properties. Therefore, appearance color, texture, taste, odor and overall acceptability were performed. Biscuits were prepared by replacing $50 \%$ of formula wheat flour $(72 \%$ ext.) with $50 \%$ sorghum whole meal flour. Data (Table 4) showed that biscuits from raw 'Dorado' variety had the highest acceptable values of color comparing with wheat biscuits.

Color is a vital quality attribute of foods and plays an important role in sensory and consumer acceptance of products which exists by millard during biscuit baking (Ghavidel and Prakash, 2006; Sowbhagya et al., 2005). Color sores were non-significant decreased after different treatments, except for germinated 'Giza-15' and fermented 'Shandaweel-6'.

Sorghum biscuits showed lower texture compared with wheat biscuits. There was a non-significant difference between different treatments in texture, except for germinated and fermented 'Dorado' biscuits compared with raw sorghum biscuits. Substitution of wheat flour with sorghum flour affected the sensory and textural characteristics of biscuits in general. Textural properties of biscuits are one of the most important features, which affect the demand for biscuits (Wade, 1988).

Sorghum biscuits showed lower texture compared with wheat biscuits. There was a non-significant difference between different treatments in texture, except for germinated and fermented 'Dorado' biscuits compared with raw sorghum biscuits. Substitution of wheat flour with sorghum flour affected the sensory and textural characteristics of biscuits in general. Textural properties of biscuits are one of the most important features, which affect the demand for biscuits (Wade, 1988).

There was a non-significant difference between different treatments in taste scores, except for biscuits prepared from germinated sorghum and fermented 'Shandaweel-6' biscuits compared with biscuits prepared from raw sorghum. Generally, the mouths feel of the biscuits was affected by the presence of sorghum, which leads to a residual taste (Mridula et al., 2007).

From results it could be noticed that sorghum biscuits prove lower overall acceptability compared

Table 4. Organoleptic evaluation of sorghum biscuits

\begin{tabular}{|c|c|c|c|c|c|c|}
\hline Treatments & Appearance -20 & Color -20 & Texture -20 & Odor -20 & Taste -20 & Overall acceptability- 100 \\
\hline Wheat biscuit & $18.70 \pm 1.42^{\mathrm{a}}$ & $18.60 \pm 1.58^{\mathrm{ab}}$ & $19.50 \pm 0.71^{\mathrm{a}}$ & $19.60 \pm 0.84^{\mathrm{a}}$ & $19.60 \pm 0.52^{\mathrm{a}}$ & $96.00 \pm 4.24^{\mathrm{a}}$ \\
\hline \multicolumn{7}{|l|}{ Raw } \\
\hline 'Dorado' & $18.40 \pm 1.27^{\mathrm{ab}}$ & $19.05 \pm 0.83^{\mathrm{a}}$ & $18.90 \pm 1.10^{\mathrm{ab}}$ & $19.40 \pm 0.84^{\mathrm{ab}}$ & $18.30 \pm 1.64^{\mathrm{ab}}$ & $94.05 \pm 4.03^{\mathrm{ab}}$ \\
\hline 'Shandaweel-6' & $18.30 \pm 1.25^{\mathrm{ab}}$ & $18.35 \pm 1.11^{\mathrm{ab}}$ & $18.15 \pm 1.45^{\mathrm{abcd}}$ & $19.10 \pm 1.29^{\mathrm{abc}}$ & $17.35 \pm 2.14^{\mathrm{b}}$ & $91.25 \pm 5.97^{\mathrm{abc}}$ \\
\hline 'Giza-15’ & $18.00 \pm 1.89^{\mathrm{ab}}$ & $18.40 \pm 1.84^{\mathrm{ab}}$ & $18.40 \pm 1.51^{\mathrm{abc}}$ & $18.75 \pm 1.14^{\mathrm{abcde}}$ & $17.40 \pm 1.58^{\mathrm{b}}$ & $90.95 \pm 6.56^{\mathrm{abc}}$ \\
\hline \multicolumn{7}{|l|}{ Soaking } \\
\hline 'Dorado' & $18.10 \pm 2.08^{\mathrm{ab}}$ & $18.60 \pm 1.71^{\mathrm{ab}}$ & $18.30 \pm 1.42^{\mathrm{abcd}}$ & $19.05 \pm 1.05^{\mathrm{abcd}}$ & $17.50 \pm 1.27^{b}$ & $91.75 \pm 6.42^{\mathrm{abc}}$ \\
\hline 'Shandaweel-6' & $17.25 \pm 1.51^{\mathrm{abc}}$ & $17.50 \pm 1.58^{\mathrm{abc}}$ & $18.20 \pm 0.92^{\mathrm{abcd}}$ & $19.00 \pm 1.07^{\mathrm{abcde}}$ & $17.60 \pm 1.71^{\mathrm{b}}$ & $89.55 \pm 4.95^{\mathrm{abcd}}$ \\
\hline 'Giza-15’ & $17.90 \pm 1.85^{\mathrm{ab}}$ & $18.35 \pm 1.50^{\mathrm{ab}}$ & $18.10 \pm 0.88^{\mathrm{abcd}}$ & $18.70 \pm 1.34^{\mathrm{abcde}}$ & $17.45 \pm 1.54^{b}$ & $90.50 \pm 5.94^{\mathrm{abcd}}$ \\
\hline \multicolumn{7}{|l|}{ Cooking } \\
\hline 'Dorado' & $17.90 \pm 1.52^{\mathrm{ab}}$ & $18.10 \pm 0.99^{\mathrm{ab}}$ & $17.70 \pm 1.16^{\text {bcde }}$ & $18.60 \pm 1.27^{\mathrm{abcde}}$ & $16.50 \pm 1.78^{\mathrm{bcd}}$ & $88.80 \pm 5.27^{\mathrm{abcde}}$ \\
\hline 'Shandaweel-6' & $17.25 \pm 1.44^{\mathrm{abc}}$ & $17.25 \pm 1.62^{\mathrm{abc}}$ & $17.90 \pm 1.52^{\mathrm{abcd}}$ & $18.60 \pm 1.27^{\mathrm{abcde}}$ & $17.00 \pm 1.25^{\mathrm{bc}}$ & $88.00 \pm 6.31^{\text {bcdef }}$ \\
\hline ‘Giza-15’ & $18.10 \pm 0.88^{\mathrm{ab}}$ & $18.20 \pm 1.40^{\mathrm{ab}}$ & $18.20 \pm 1.55^{\mathrm{abcd}}$ & $18.40 \pm 1.17^{\mathrm{abcde}}$ & $16.65 \pm 1.10^{\mathrm{bcd}}$ & $89.55 \pm 5.03^{\mathrm{abcd}}$ \\
\hline \multicolumn{7}{|l|}{ Germination } \\
\hline 'Dorado' & $17.25 \pm 1.62^{\mathrm{abc}}$ & $16.90 \pm 2.23^{\mathrm{bc}}$ & $17.20 \pm 1.55^{\mathrm{cde}}$ & $17.70 \pm 1.89^{\text {bcde }}$ & $15.50 \pm 1.49^{\mathrm{cd}}$ & $84.55 \pm 6.93^{\text {cdef }}$ \\
\hline 'Shandaweel-6' & $16.80 \pm 2.15^{\mathrm{bc}}$ & $17.50 \pm 2.07^{\mathrm{abc}}$ & $16.15 \pm 2.52^{\mathrm{e}}$ & $17.50 \pm 2.51^{\text {cde }}$ & $15.25 \pm 1.99^{\mathrm{cd}}$ & $83.40 \pm 9.94^{\text {def }}$ \\
\hline 'Giza-15’ & $16.00 \pm 2.26^{c}$ & $16.20 \pm 1.75^{c}$ & $16.60 \pm 1.78^{\mathrm{de}}$ & $18.30 \pm 1.57^{\mathrm{abcde}}$ & $15.00 \pm 2.44^{\mathrm{d}}$ & $82.00 \pm 8.15^{\mathrm{ef}}$ \\
\hline \multicolumn{7}{|l|}{ Fermentation } \\
\hline 'Dorado' & $16.70 \pm 1.90^{\mathrm{bc}}$ & $17.10 \pm 1.97^{\mathrm{bc}}$ & $16.80 \pm 1.87^{\text {cde }}$ & $17.35 \pm 2.33^{\text {de }}$ & $16.65 \pm 1.70^{\mathrm{bcd}}$ & $84.60 \pm 7.98^{\text {cdef }}$ \\
\hline 'Shandaweel-6' & $15.70 \pm 1.89^{c}$ & $16.00 \pm 2.05^{c}$ & $16.70 \pm 2.06^{\mathrm{cde}}$ & $17.30 \pm 2.31^{\mathrm{e}}$ & $15.55 \pm 2.17^{\mathrm{cd}}$ & $81.35 \pm 8.17^{\mathrm{f}}$ \\
\hline 'Giza-15’ & $17.05 \pm 2.67^{a b c}$ & $16.85 \pm 2.66^{\mathrm{bc}}$ & $16.70 \pm 2.45^{\text {cde }}$ & $17.90 \pm 2.38^{\mathrm{abcde}}$ & $16.75 \pm 2.02^{\mathrm{bcd}}$ & $85.45 \pm 8.74^{\mathrm{cdef}}$ \\
\hline L.S.D & 1.5714 & 1.5399 & 1.4224 & 1.4276 & 1.5080 & 6.1822 \\
\hline
\end{tabular}

Values are mean of ten replicates $\pm S D$, values in the same column followed by the same letter are not significantly different at 0.05 level 
with wheat biscuits. Overall acceptability of germinated and fermented biscuits decreased compared with other treatments. Moreover, sorghum whole meal flour could be used for making acceptable quality biscuits up to $50 \%$ levels of replacement. Mridula et al. (2007) found that addition of sorghum flour reduced the overall quality of biscuits. Higher fiber content in sorghum flour than wheat flour might be attributed to the increased toughness of the biscuits in proportion to the sorghum flour levels. Although the biscuits samples with higher proportion of sorghum flour were tougher as compared to control biscuits, they were found acceptable on sensory evaluation (Wade, 1988).

\section{Physical properties and hardness of biscuits}

Table 5 summarise the data upon the physical properties of sorghum biscuits at different treatments. It confirmed that the weight of sorghum biscuits was non-significant different compared with wheat biscuits, except for biscuits prepared from raw 'Shandaweel-6', germinated 'Giza-15' and fermented 'Giza-15'.

Thickness of sorghum biscuits was non-significant different compared with wheat biscuits and all treatments. Substitution of wheat flour with sorghum flour affected the physical characteristics of biscuits in general. The thickness depends not only upon the aerating agents present, but also on the conditions existing in the oven (Sowbhagya et al., 2005; Wade, 1988)

The amount of spread during baking of short and soft dough products is affected by formulation of the dough, ingredients' properties, the type of baking surface and by the condition in the oven (Sowbhagya et al., 2005). The density of sorghum biscuits was non-significant different compared with wheat biscuits, except for biscuits prepared from raw 'Dorado' and fermented 'Shandaweel-6' and 'Giza-15'. This is due to the decrease in width and thickness of these three types of biscuits. There were no significant differences between the weight, thickness and spread ratios of $100 \%$ wheat flour biscuits compared to that of sorghum-wheat composite flour biscuits (Adebowale et al., 2012). On the other hand, density of biscuits decreased with addition of sorghum (Wade, 1988).

The same data (Table 5) presents the hardness of sorghum biscuits at different treatments. The hardness of sorghum flour incorporated biscuits was compared with that of wheat biscuits. Hardness of sorghum biscuits was significant decreased in all treatments compared with wheat biscuits. Hardness values of germinated sorghum biscuits were higher than other treatments and close to wheat biscuits values. The hardness of sorghum flour incorporated biscuits up to $20 \%$ was comparable with the control biscuits (Wade, 1988). A decrease was observed in biscuits' hardness at 50 and $60 \%$ sorghum flour levels. Mridula et al. (2007) found that increasing of sorghum flour content, hardness, toughness, average breaking force and average breaking energy of biscuit samples also increased.

It could be concluded that addition of $50 \%$ sorghum whole meal flour at different treatments could be recommended for production of biscuits. The use of sorghum in biscuits making would greatly enhance the utilization of this crop as substitute in food products, where the sorghum has not been optimally utilized.

\section{Acknowledgements}

Authors would like to thank the Faculty of Agriculture, Cairo University, Department of biochemistry and Food Technology Research Institute, Agricultural Research Center for ongoing collaboration to support research and that provided funds and facilities necessary to accomplish the desired goals of research.

Table 5. Physical properties and hardness of sorghum biscuits

\begin{tabular}{|c|c|c|c|c|c|c|}
\hline Treatments & Weight & Diameter & Thickness & Spread ratio & Density & Hardness \\
\hline Wheat biscuit & $6.53 \pm 0.16^{\mathrm{defg}}$ & $44.49 \pm 0.04^{c}$ & $6.87 \pm 0.53^{\mathrm{abc}}$ & $6.48 \pm 0.49^{\text {cde }}$ & $0.59 \pm 0.09^{\text {cd }}$ & $14.61 \pm 1.67^{\mathrm{a}}$ \\
\hline \multicolumn{7}{|l|}{ Raw } \\
\hline 'Dorado' & $6.33 \pm 0.31^{g}$ & $46.97 \pm 0.20^{\mathrm{a}}$ & $6.52 \pm 0.04^{c}$ & $7.24 \pm 0.08^{\mathrm{a}}$ & $0.53 \pm 0.02^{\mathrm{e}}$ & $7.46 \pm 1.37^{\mathrm{e}}$ \\
\hline 'Shandaweel-6' & $7.75 \pm 0.09^{\mathrm{a}}$ & $46.32 \pm 0.70^{\mathrm{ab}}$ & $7.15 \pm 0.09^{\mathrm{ab}}$ & $6.48 \pm 0.03^{\mathrm{cde}}$ & $0.61 \pm 0.06^{\mathrm{bc}}$ & $8.11 \pm 1.71^{\mathrm{e}}$ \\
\hline 'Giza-15’ & $6.43 \pm 0.10^{\mathrm{fg}}$ & $46.01 \pm 0.18^{\mathrm{ab}}$ & $6.92 \pm 0.46^{\mathrm{abc}}$ & $6.67 \pm 0.44^{\text {bcde }}$ & $0.63 \pm 0.02^{\mathrm{abc}}$ & $8.57 \pm 2.04^{\mathrm{de}}$ \\
\hline \multicolumn{7}{|l|}{ Soaking } \\
\hline 'Dorado' & $6.89 \pm 0.19^{\text {bcde }}$ & $45.74 \pm 0.45^{b}$ & $7.19 \pm 0.19^{\mathrm{ab}}$ & $6.37 \pm 0.11^{\mathrm{de}}$ & $0.64 \pm 0.02^{\mathrm{abc}}$ & $8.96 \pm 2.00^{\text {cde }}$ \\
\hline 'Shandaweel-6' & $6.86 \pm 0.32^{\text {bcdef }}$ & $46.36 \pm 0.34^{\mathrm{ab}}$ & $6.60 \pm 0.43^{\mathrm{bc}}$ & $7.04 \pm 0.42^{\mathrm{ab}}$ & $0.66 \pm 0.01^{\mathrm{ab}}$ & $7.35 \pm 0.10^{\mathrm{e}}$ \\
\hline 'Giza-15’ & $6.45 \pm 0.39^{\mathrm{efg}}$ & $46.06 \pm 1.35^{\mathrm{ab}}$ & $6.82 \pm 0.24^{\mathrm{abc}}$ & $6.84 \pm 0.08^{\mathrm{abcd}}$ & $0.66 \pm 0.01^{\mathrm{ab}}$ & $9.12 \pm 1.67^{\text {bcde }}$ \\
\hline \multicolumn{7}{|l|}{ Cooking } \\
\hline 'Dorado' & $6.42 \pm 0.29^{\mathrm{fg}}$ & $45.57 \pm 0.29^{b}$ & $6.37 \pm 0.24^{c}$ & $7.16 \pm 0.22^{\mathrm{ab}}$ & $0.67 \pm 0.04^{\mathrm{ab}}$ & $8.54 \pm 0.68^{\mathrm{de}}$ \\
\hline 'Shandaweel-6' & $6.46 \pm 0.23^{\mathrm{efg}}$ & $45.75 \pm 0.82^{b}$ & $6.33 \pm 0.10^{c}$ & $7.22 \pm 0.08^{\mathrm{a}}$ & $0.69 \pm 0.07^{\mathrm{a}}$ & $9.42 \pm 0.98^{\mathrm{bcde}}$ \\
\hline 'Giza-15’ & $6.54 \pm 0.20^{\operatorname{defg}}$ & $46.14 \pm 0.25^{\mathrm{ab}}$ & $6.49 \pm 0.20^{c}$ & $7.11 \pm 0.25^{\mathrm{ab}}$ & $0.65 \pm 0.07^{\mathrm{abc}}$ & $10.00 \pm 0.60^{\text {bcde }}$ \\
\hline \multicolumn{7}{|l|}{ Germination } \\
\hline 'Dorado' & $6.63 \pm 0.20^{\text {cdefg }}$ & $46.25 \pm 0.39^{\mathrm{ab}}$ & $6.92 \pm 0.18^{\mathrm{abc}}$ & $6.69 \pm 0.12^{\text {bcde }}$ & $0.54 \pm 0.01^{\mathrm{de}}$ & $11.37 \pm 1.76^{\mathrm{bcd}}$ \\
\hline 'Shandaweel-6' & $6.74 \pm 0.25^{\text {bcdefg }}$ & $46.28 \pm 0.15^{\mathrm{ab}}$ & $7.12 \pm 0.04^{\mathrm{ab}}$ & $6.50 \pm 0.02^{\mathrm{cde}}$ & $0.58 \pm 0.04^{\mathrm{cd}}$ & $11.50 \pm 3.97^{\mathrm{bc}}$ \\
\hline 'Giza-15’ & $7.14 \pm 0.02^{b}$ & $46.31 \pm 0.43^{\mathrm{ab}}$ & $7.40 \pm 0.04^{a}$ & $6.22 \pm 0.03^{\mathrm{e}}$ & $0.55 \pm 0.01^{\mathrm{de}}$ & $11.77 \pm 1.63^{\mathrm{bc}}$ \\
\hline \multicolumn{7}{|l|}{ Fermentation } \\
\hline 'Dorado' & $6.92 \pm 0.01^{\mathrm{bcd}}$ & $45.87 \pm 0.35^{b}$ & $6.69 \pm 0.27^{\mathrm{bc}}$ & $6.86 \pm 0.21^{\mathrm{abcd}}$ & $0.62 \pm 0.03^{\mathrm{bc}}$ & $9.62 \pm 0.78^{\text {bcde }}$ \\
\hline 'Shandaweel-6' & $6.76 \pm 0.25^{\text {bcdefg }}$ & $46.11 \pm 0.52^{\mathrm{ab}}$ & $6.33 \pm 0.19^{c}$ & $7.28 \pm 0.14^{\mathrm{a}}$ & $0.66 \pm 0.01^{\mathrm{ab}}$ & $10.10 \pm 0.69^{b c d e}$ \\
\hline 'Giza-15’ & $7.05 \pm 0.31^{\mathrm{bc}}$ & $46.13 \pm 0.40^{\mathrm{ab}}$ & $6.71 \pm 0.68^{\mathrm{bc}}$ & $6.91 \pm 0.61^{\mathrm{abc}}$ & $0.67 \pm 0.01^{\mathrm{ab}}$ & $11.96 \pm 0.88^{b}$ \\
\hline L.S.D & 0.3871 & 0.8971 & 0.5171 & 0.4613 & 0.0539 & 2.4717 \\
\hline
\end{tabular}

Values are mean of three replicates \pm SD, values in the same column followed by the same letter are not significantly different at 0.05 level 
134

\section{References}

Adebowale AA, Adegoke MT, Sanni SA, Adegunwa MO, Fetuga GO (2012). Functional properties and biscuit making potentials of sorghum-wheat flour composite. Am J Food Tech 7:372-379.

Afify AMR, El-Beltagi HS, Abd El-Salam SM, Omran AA (2011a). Bioavailability of iron, zinc, phytate and phytase activity during soaking and germination of white sorghum varieties. PLoS ONE 6(10):25512, 1-7.

Afify AMR, Rashed MM, Ebtesam AM, El-Beltagi HS (2011b). Effect of gamma radiation on protein profile, protein fraction and solubility of three oil seeds. Not Bot Horti Agrobo 39(2):90-98.

Afify AMR, El-Beltagi HS, Abd El-Salam SM, Omran AA (2012a). Biochemical changes in phenols, flavonoids, tannins, vitamin $\mathrm{E}$, $\beta$-carotene and antioxidant activity during soaking of three white sorghum varieties. APJTB 2(3):203-209.

Afify AMR, El-Beltagi HS, Abd El-Salam SM, Omran AA (2012b). Protein solubility, digestibility and fractionation after germination of sorghum varieties. PLoS ONE $7(2): 31154,1-6$.

Afify AMR, El-Beltagi HS, Abd El-Salam SM, Omran AA (2012c). Oil and fatty acid contents of white sorghum varieties under soaking, cooking, germination and fermentation for improving cereal quality. Not Bot Horti Agrobo 40(1):86-92.

Afify AMR, El-Beltagi HS, Abd El-Salam SM, Omran AA (2012d). Effect of soaking, cooking, germination and fermentation processing on proximate analysis and mineral content of three white sorghum varieties (Sorghum bicolour L. Moench). Not Bot Horti Agrobo 40(2):92-98.

Afshari-Jouybari H, Farahnaky A (2011). Evaluation of photoshop software potential for food colorimetry. J Food Engin 106:170-175.

Ahmed MM, Sanders JH, Nell WT (2000). "New sorghum and millet cultivar introduction in sub-saharan Africa: impacts and research agenda. Agric Syst 64(1):55-65.

Akpata MI, Miachi OE (2001). Proximate composition and selected functional properties of Detarium microcarpum. Plant Foods Human Nutr 56:297-302.

Almeida-Dominguez HD, Rooney LW (1997). Quality control laboratory guidelines: Analytical techniques for the corn alkaline cooking industry. Texas Univ, Texas, $90 \mathrm{p}$.

Awika JM, Suhendro EL, Rooney LW (2002). Milling value of sorghums compared by adjusting yields to a constant product color. Cereal Chem 79(2):249-251.

Awika JM, Rooney LW, Wu X, Prior RL, Cisneros-Zevallos L (2003). Screening methods to measure antioxidant activity of sorghum (Sorghum bicolor) and sorghum products. J Agric Food Chem 51:6657-6662.

Awika JM, Rooney LW (2004). Sorghum phytochemicals from and their impact on human health. Phytochem 65:1199-1221.

Beuchat LR (1977). Functional and electrophoretic characteristics of succinylated peanut flour protein. J Agric Food Chem 25:258-261.
Ciacci C, Maiuri L, Caporaso N, Bucci C, Del Giudice L, Rita Massardo D, Pontieri P, Di Fonzo N, Bean SR, Ioerger B, Londei M (2007). Celiac disease: in vitro and in vivo safety and palatability of wheat-free sorghum food products. Clin Nutr 26:799-805.

da Silva LS, Taylor JRN (2004). Sorghum bran as a potential source of kafirin. Cereal Chem 81(3):322-327.

Dicko MH, Gruppen H, Traoré AS, Voragen AGJ, van Berkel WJH (2006). Sorghum grain as human food in Africa: relevance of content of starch and amylase activities. African J Biotech 5(5):384-395.

El-Beltagi HS (2011). Effect of roasting treatments on protein fraction profiles, some enzyme activities of Egyptian peanuts. Inter J Food Sci Nutr 62(5):453-456.

El-Beltagi HS, Salama ZA, El-Hariri DM (2011). Variations in oil and some phytochemical contents in flax seed cultivars (Linum usitatissimum L.). EJEAFChe 10(8):2711-2721.

Elkhalifa AO, El-Tinay AH (2002). Effect of cysteine on bakery products from wheat sorghum blends. Food Chem 77:133-137.

Elkhalifa AO, Schiffler B, Bernhardt R (2005). Effect of fermentation on the functional properties of sorghum flour. Food Chem 92:1-5.

Elkhalifa AO, Bernhardt R (2010). Influence of grain germination on functional properties of sorghum flour. Food Chem 121:387-392.

Etudaiye HA, Nwabueze TU, Sanni LO (2009). Quality of fufu processed from cassava mosaic disease (CMD) resistant varieties. African J Food Sci 3(3):61-67.

FAO/WFP (2007). Special report FAO/WFP crop and food supply assessment mission to Sudan.

Fathi M, Mohebbi M, Razavi MA (2009). Application of image analysis and artificial neural network to predict mass transfer kinetics and color changes of osmotically dehydrated kiwi fruit. Food Bioprocess Tech. Disponivelem: <http.//dx.doi.org>. doi:10.1007/s11947009-0222-y.

Gaines CS (1991). Instrumental measurement of the hardness of cookies and crackers. Cereal Foods World 36:989-996.

Gernah DI, Ariahu CC, Ingbian EK (2011). Effect of malting and lactic fermentation on some chemical and functional properties of maize (Zea mays). Am J Food Tech 6(5):404412.

Ghavidel RA, Prakash J (2006). Effect of germination and dehulling on functional properties of legume flours. J Sci Food Agric 86:1189-1195.

Hahn DH, Rooney LW (1985). Effect of genotype on tannin and phenols of sorghum. Cereal Chem 63(1):4-8.

Hussein HM, Hussein MM, El-Damohery ST (2006). The effect of natural formulated functional biscuits on elderly bone health. J Med Sci 6:937-943.

Iwegbue CMA (2012). Metal contents in some brands of biscuits consumed in southern Nigeria. Am J Food Tech 7:160-167.

Kayodé APP (2006). Diversity, Users' Perception and Food 
Processing of Sorghum: Implications for Dietary Iron and Zinc Supply. Ph.D. Thesis, Wageningen Univ., Netherlands, Wageningen, $151 \mathrm{p}$.

Kure OA, Bahayo EJ, Daniel EA (1998). Studies on the proximate composition and effect of flour particle size on acceptability of biscuit produced from blends of soya beans and plantain flour. Namida Tech-Scope T 3:17-21.

Larmond E (1977). Laboratory methods for sensory evaluation of foods. Canadian Department of Agriculture, Otawa, Canada, 1-1637 p.

Lee WJ, Pedersen JF, Shelton DR (2002). Relationship of Sorghum kernel size to physiochemical, milling, pasting, and cooking properties. Food Res Inter 35:643-649.

Mepba HD, Eboh L, Nwaojigwa SU (2005). Chemical composition, functional and bakink properties of wheatplantain composite flours. Afr J Food Agric Nutr Dev 7:122.

Mohammed MAE, Makki HMM, Mustafa AEMI (2011). Production of cereal-based infant food from sorghum [Sorghum bicolor (L) Moench] and pigeon pea (Cajanus cajan). Pak J Nutr 10:910-913.

Mridula D, Gupta RK, Manikantan MR (2007). Effect of incorporation of sorghum flour to wheat flour on quality of biscuit fortified with defatted soy flour. Am J Food Tech 2(5):428-434.

Mwithiga G, Sifuna MM (2006). Effect of moisture content on the physical properties of three varieties of sorghum seeds. J Food Eng 75:480-486.

Ndirika VIO, Mohammed SS (2005). Determination of selected physical properties and their relationship with moisture content for sorghum crop. J Food Tech 3(3):314318.

Ngwenya NR (2007). Effect of sorghum type and processing on the antioxidant properties of sorghum [Sorghum bicolour (L.).Moench] based foods. PhD Thesis, Fac Food Sci Tech, Texas Univ, Texas, 130 p.

Onwueme IC, Sinha TD (1993). Field Crop Production in Tropical Africa, CTA, Ede, The Netherlands, 480 p.

Ogu EO, Odibo FJC, Agu RC, Palmer GH (2006). Quality assessment of different sorghum varieties for their brewing potential. J Instit Brewing 112(2):117-121.

Okrah SG (2008). Screening of Six Local Sorghum Varieties for their Malting and Brewing Qualities. MSc Thesis, Kwame Nkrumah Univ Sci Tech, Ghana, 87 p.
Omobuwajo TO (2003). Compositional characteristics and sensory quality of biscuits, prawn crackers and fried chips produced from beadfruit. Innovative Food Sci Emerging Tech 4:219-225.

Osungbaro TO, Jimoh D, Osundeyi E (2010). Functional and pasting properties of composite cassava-sorghum flour meals. Agric Biol J North Am 1(4):715-720.

Oyarekua MA, Adeyeye EI (2009). Comparative evaluation of the nutritional quality, functional properties and amino acid profile of co-fermented maize/cowpea and sorghum/cowpea Ogi as infant complementary food. Asian J ClinNutr 1:31-39.

Pontieri P, Di Maro A, Tamburino R, De Stefano M, Tilley M, Bean S, Roemer E, DE Vita P, Alifano P, Del Giudice L, Massardo D (2010). Chemical composition of selected food-grade sorghum varieties grown under typical Mediterranean conditions. Maydica 55:139-143.

Sowbhagya HB, Smitha S, Sampathu SR, Krishnamurthy N, Bhattacharya $S$ (2005). Stability of water-soluble turmeric colourant in an extruded food product during storage. $\mathrm{J}$ Food Engin 67:367-371.

Traoré, T, Mouquet C, Icard-Verniere C, Traore AS, Treche S (2004). Changes in nutrient composition, phytate and cyanide contents and $\alpha$-amylase activity during cereal malting in small production units in Ouagadougou (Burkina Faso). Food Chem 88:105-114.

Wade P (1988). Biscuits, cookies and crackers, the principles of the craft. Elsevier Applied Science, New York, 1, pp.1176.

Wan P, Long C, Huang X (2011). A detection method of rice process quality based on the color and BP Neural Network. Conference of the 4th Computer and Computing Technologies in Agriculture. Oct 22-25; Nanchang. China. v. 344, p. 25-34

Whiteley PR (1971). Biscuit manufacture- fundamentals of InLine production. Elsevier Publishing Company, Amsterdam, p. 1-319.

Zhao R, Bean SR, Ioerger BP, Wang D, Boyle DL (2008). Impact of mashing on sorghum proteins and its relationship to ethanol fermentation. J Agric Food Chem 56(3):946953. 